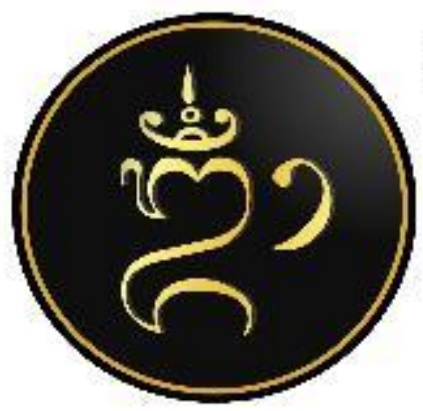

E-ISSN: $2722-8576$

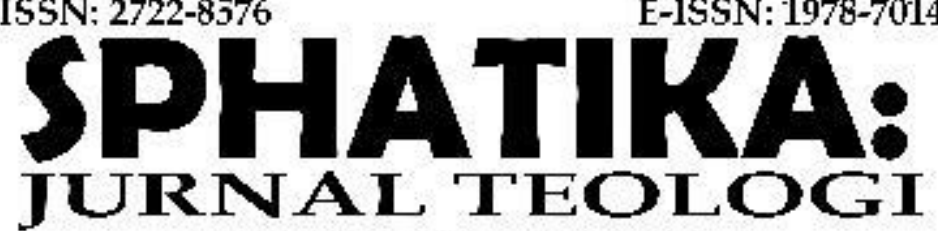

UNIVERSITAS HINDU NEGER]

I GUSTI BAGUS SUGIRIWA IOENPASAR

VULINF 12 NUMUR 1, MARET 2021

\title{
IMPLIKASI COVID-19 TERHADAP NILAI KESUSILAAN PERSFEKTIF TEOLOGI MORAL
}

\author{
I Wayan Sunampan Putra ${ }^{1}$ \\ 1Sekolah Tinggi Agama Hindu Negeri Mpu Kuturan Singaraja \\ 1sunamfan91@gmail.com
}

Keywords: covid-19; moral theology
Kata kunci: covid19; teologi moral
Abstract (Justify, Italic and Bold, book antiqua 11)

The Phenomenon of Covid-19 is one of the problems faced by the public. This can be seen in most busy countries to deal with the spread of Covid-19. Various ways are done to limit or reduce its spread. Such rapid dissemination causes fear and unrest in people's lives, both physically and psychically. This paper aims to outline the implications of Covid-19 in every human life. Also, the spread of Covid-19 has a profound impact on people's lives in various aspects such as economic growth, social relations, and moral issues. Maanfaat from this paper that provides an overview of the implications on the value of decency, so that it can be used as a reprensi in finding solutions to handling Covid-19.

Abstrak (rata kanan kiri, cetak miring dan tebal, book antiqua 11)

Fenomena Covid-19 merupakan salah satu masalah yang dihadapi oleh masyarakat luas. Ini dapat dilihat sebagian besar negara sibuk untuk menangani penyebaran Covid-19. Berbagai cara dilakukan untuk membatasi ataupun mengurangi penyebarannya. Penyebaran yang begitu cepat menimbulkan ketakutan dan keresahan dalam kehidupan masyarakat, baik secara fisik maupun psikis. Tulisan ini bertujuan untuk menguraikan implikasi Covid-19 dalam setiap kehidupan manusia. Mengingat juga, penyebaran Covid-19 sangat berdampak bagi kehidupan masyarakat dalam berbagai aspek seperti pertumbuhan ekonomi, hubungan sosial, serta masalah moral. Maanfaat dari tulisan ini yakni memberikan gambaran mengenai implikasi terhadap nilai kesusilaan, sehingga bisa dijadikan reprensi dalam mencari solusi penanganan Covid-19 


\section{PENDAHULUAN}

Dewasa ini, dunia dihebohkan dengan fenomena Covid-19 yang merabah ke berbagai belahan negara. Penyebarannya yang begitu cepat membuat ketakutan yang sangat dirasakan oleh masyarakat. Bagaimana tidak, penyebaran yang terjadi bisa mempengaruhi tidak saja kesehatan secara fisik, akan tetapi juga dapat mempengaruhi kesehatan secara psikis. Secara psikis, terlihat dari ketakutan ataupun kecemasan masyarakan terhadap Covid-19. Rasa cemas terkadang dapat berdampak pada kesehatan secara fisik, sehingga Covid-19 ini memiliki dampak yang sangat kompleks bagi kehidupan manusia karena dapat menyerang berbagai aspek.

Penyebaran Covid-19 merupakan sebuah fenomena global, karena hampir sebagian besar negara dilanda oleh penyebaran Covid-19 ini. Berbagai cara pun dilakukan dalam pemutus penyebarannya seperti: pembatasan sosial, pembatasan kegiatan masyarakat, penutupan sejumlah tempat. Namun, sampai saat ini penyebaran Covid-19 masih saja terjadi, hal ini dapat dilihat dari masih bertambahnya korban yang terkena Covid-19 serta korban yang meninggal dinyatkan terkontaminasi. Hal ini membuat masyarakat masih memiliki rasa takut terhadap penyebaran Covid-19 ini.

Penyebaran yang kian masif sangat berpengaruh pada kegiatan aktifitas masyarakat, ini dikarenakan adanya pembatasan sosial serta pembatasan kegiatan masyarakat, bahkan kegiatan-kegiatan yang sangat vital juga terdampak seperti aktifitas bekerja, berintraksi, serta kegiatan upacara keagamaan. Segala bentuk pembatasan mengakibatkan adanya implikasi lain seperti krisis ekonomi yang mana masyarakat mengalami pemutusan hubungan kerja, penutupan tempat usaha. Hal ini memicu banyaknya pengangguran yang terjadi dalam kehidupan masyarakat. Selain adanya masalah ekonomi, masalah sosial pun ikut terpengaruh. Pembatasan sosial yang dilakukan adalah suatu bentuk pembatasan intraksi sosial antar individu maupun masyarakat. Hal ini menjadi suatu kesulitan bagi masyarakat mengingat manusia pada daarnya adalah makluk sosial.

Masalah ekonomi serta masalah sosial yang diakibatkan oleh penyebaran Covid19 juga menimbulkan masalah moral, hal ini terlihat dari hubungan antar sesama yang kurang baik karena ada pembatasan sosial, serta maraknya pristiwa kriminal yang terjadi dimasa pandemi ini, seperti pencurian. Pencurian merupakan masalah moral dalam lingkungan masyarakat. Pencurian bisa terjadi dikarenakan terdesak oleh kebutuhan hidup, maka terkadang seseorang mencari jalan keluar dengan cara mencuuri sesuatu yang dianggap bisa dipergunakan dalam memenuhi kebutuhan 
hidup. Terkait dengan hal tersebut maka tulisan ini mencoba menguraikan implikasi dari fenomena Covid-19 dengan meninjau aspek moral serta kaitannya dengan aspek teologis.

\section{METODE}

Metode adalah suatu cara, jalan, petunjuk pelaksanaan atau petunjuk teknis sehingga memiliki sifat yang praktis (Kaelan, 2005:7). Metode juga dapat diartikan sebagai cara kerja yang dipergunakan untuk memahami suatu obyek penelitian agar data yang diperoleh mencapai hasil yang optimal. Metode penelitian adalah suatu cara yang dilakukan dalam sebuah penelitian untuk mendapatkan pengetahuan yang baru. Penelitian mengenai Implikasi Covid-19 terhadap nilai kesusilaan persfektif teologi moral menggunakan metode pendekatan deskriptif kualitatif. Penelitian kualitatif merupakan penelitian yang berhubungan dengan ide, persepsi, pendapat, kepercayaan orang yang akan diteliti dan kesemuanya tidak dapat diukur dengan angka.

\section{PEMBAHASAN}

\section{Fenomena Covid-19}

Sejak awal tahun 2020 dunia dilanda merebaknya Covid-19. Bukan hanya negara yang disibukkan oleh fenomena yang muncul tiba-tiba ini, tapi juga organisasi, bahkan individu. Pada awal munculnya fenomena ini masih dianggap biasa dan lokal, yakni hanya merabah di tempat pertama kali muncul yaitu di Wuhan Cina. Namun di luar perkiraan, dunia dibangunkan secara paksa dari rasa aman dan nyaman ketika korban meninggal telah mencapai ribuan. Yang paling mengawatirkan adalah bahwa korban dari fenomena ini sampai pada negara Indonesia dan Bali pada khususnya. Walaupun dari penelsuran peristiwa wabah beberapa virus telah pernah merambah, namun fenomena Covid-19 adalah peristiwa yang paling mencekam apalagi didukung oleh distribusi informasi yang sangat pesat dari berbagai media khususnya dari media sosial.

Dengan menyimak uraian berita di https://bangka.tribunnews.com/2020/03 Covid-19 adalah penyakit yang disebabkan oleh infeksi virus SARS-CoV-2, pertama kali diidentifikasi di kota Wuhan, di provinsi Hubei Cina pada Desember 2019. Covid-19 telah menyebar ke berbagai negara di dunia, termasuk Indonesia. Gejala Covid-19 yang paling umum adalah batuk kering, demam, dan sesak napas. Diperkirakan bahwa gejala dapat muncul antara 2-14 hari setelah paparan walaupun ada kasus terisolasi yang menunjukkan ini mungkin lebih lama. Jika mengalami gejala, diharapkan tinggal di 
rumah untuk mencegah penyebaran penyakit ke masyarakat. Mengenakan masker wajah akan membantu mencegah penyebaran penyakit ke orang lain.

\section{Implikasi Covid-19}

Fenomena Covid-19 yang melanda saat ini, banyak memberikan implikasi bagi kehidupan manusia. Masifnya penyebaran Covid-19 yang telah menyerang berbagi lini menyebabkan masyarakat bisa merasakan dampaknya. Dampak yang sangat terasa yakni, krisis ekonomi, krisis, sosial, serta krisis moral.

\subsection{Krisis Ekonomi}

Ekonomi merupakan sesuatu yang sangat vital dalam kehidupan manusia, sehingga aspek ekonomi tidak terlepas dari kehidupan manusia. Dalam ajaran moral manusia juga memiliki tujuan hidup yang tidak terlepas dari arta sebagi bentuk ekonomi. Ajaran Catur Purusa Arta merupakan ajaran yang menekankan tujuan hidup manusia. Catur Purusa Artha artinya empat tujuan hidup sebagai manusia yakni: Dharma merupakan kebenaran, Artha merupakan kekayaan material, Kama merupakan keinginan untuk memperoleh kenikmatan, serta Moksa yang merupakan kebebasan dari unsur materi untuk mencapai kebahagian yang hakiki. Beranjak dari hal tersebut, maka manusia tidaklah salah jika memenuhi kehidupan ekonomi dalam hidupnya untuk mencapai kehidupan yang sejahtra berdasarkan ajaran agama Hindu.

Namun fenomena Covid-19 justru mengantarkan manusia pada krisis ekonomi. Hal ini terlihat dari penutupan aktifitas kerja masyarakan dalam berbagai sektor, sehingga masyarakat yang tidak beruntung harus menerima dampak dari pandemi Covid-19 berupa pemutusan hubungan kerja, penutupan tempat usaha karena adanya pembatasan sosial serta harga-harga hasil pertanian yang anjlok. Hal ini mengakibatkan terjadinya krisis ekonomi masyarakat. Padahal, satu sisi kehidupan manusia tidak terlepas dari aspek ekonomi untuk menjalani kehidupan. Arta sebagai tujuan hidup manusia menjadi terhambat dalam proses pencapaiannya. Apalagi dewasa ini arta merupakan hal yang snagat penting dari kehidupan ekonomi.

Fenomena Covid-19 yang berdampak pada krisis ekonomi secara individu begitu terasa. Dengan mengutip berita online (www.detik.com, 11/04/2020) kerugian dari fenomena Covid-19 secara pribadi yakni: 1) Hilangnya gaji atau tunjangan selama masa krisis, atau hilangnya pemasukan bagi pelaku usaha/profesi informal, 2) Denda/bunga akibat telat atau tidak bayar kewajiban, 3) Pengeluaran ekstra bagi anggota keluarga 
dalam kondisi darurat, 4) Bunga utang baru apabila menggunakan dan talangan, 5) Kerugian tak ternilai apabila krisis itu mengakibatkan hilangnya. Krisis ekonomi yang dialami akibat dari pandemi Covid-19 membuat manusia terjebak pada tindakantindakan penyimpangan moral agar dapat memenuhi kebutuan hidup.

Krisis ekonomi yang semakin terasa membuat seseorang mencari jalan singkat untuk mendapatkan materi apalagi didorong oleh rasa takut jika tidak dapat memenuhi kebutuhan ataupun keinginan yang semakin menuntut, maka banyak kasus pencurian saat ini marak terjadi untuk mendapatkan materi. Padahal dalam ajaran agama Hindu manusia diarahkan bekerja dengan motivasi yadnya. Melakukan pekerjaan tanpa memikirkan hasil. Dengan dapat mengaplikasikan sistem kerja dalam prinsif agama Hindu maka dampak dari krisis ekonomi akan bisa dimanjeman. Dengan mengutip sloka Bhagawad Gita. III.19

tasmad asaktah satatam karyam karma samacara, asakto hy acaran karma param apnoti purusha

Terjemahannya:

Oleh karena itu,

laksanakanlah segala kerja sebagai segala kewajiban tanpa terikat (pada akibatnya), sebab dengan melakukan kegiatan kerja yang bebas dari keterikatan, orang itu sesungguhnya mencapai yang utama (Pudja, 2013: 90)

Uraian sloka tersebut, menekankan bahwa seseorang dituntun untuk bekerja sebagai bentuk kewajiban dan tidak melihat hasil terlebih dahulu. Maka, walaupun masa pandemi Covid-19 yang membatasi segala aktifitas setidaknya seseorang bisa tetap melakukan kerja, serta fenomena ini tidak dijadikan alasan untuk tidak bekerja, karena nantinya bisa mengarah pada masalah perekonomian.

\subsection{Krisis Sosial}

Kehidupan manusia pada hakekatnya tidak bisa lepas dari ranah sosial karena selain sebagai makluk individu manusia juga sebagai makluk sosial. Hal ini sesuai dengan Kuypers (Santosa, 2010: 158) menguraikan manusia sebagai makluk sosial berarti manusia dituntut untuk senantiasa melakukan hubungan dengan individu lain dalam hidupnya, sejak ia membentuk pribadinya, sampai ia meninggal dunia, dimanapun individu itu berada. Hal ini menyebabkan manusia sebagai makluk sosial tidak dapat hidup sendiri di tengah-tengah bergaulan manusia.

Lebih lanjut Durkheim (Santosa, 2010: 158) mengemukakan bahwa setiap individu memiliki tingkah laku psikologis dan sosiologis. Tingkah laku psikologis lebih 
mengarah pada manusia sebagai makluk individu. Sedangkan tingkah laku sosiologis maka tingkah laku yang dilakukan ditunjukan untuk berhubungan dengan individu yang lain dalam pergaulan hidup sehari-hari. Namun, fenomena Covid-19 justru berdampak pada krisis sosial yang memperlihatkan adanya pembatasan sosial bersekala besar (PSBB). Pembatasan sosial terjadi karena himbauan pemerintah untuk tidak melakukan aktifitas sosial, apalagi adanya sangsi jika melanggar PSBB yang diberlakukan oleh pemerintah. Pembatasan sosial juga terjadi oleh dorongan individu yang terdorong oleh rasa takut dengan orang lain jika berintraksi dengan orang lain. Hal ini memperlihatkan adanya penutupan diri baik secara langsung dengan menutup diri secara simbolik.

Hubungan sosial pada dasarnya tertuang dalam ajaran-ajaran teologi yang berorientasi pada moral yang biasa disebut teologi moral. Ini terlihat dari kehidupan sosial yang seharusnya dikembangkan antara individu sesuai dengan rujukan teks dalam Hindu pada teks Artharvaveda III. 30. 4 yakni:

Yena devāna viyanti no ca vidvisate mithah, tat krnmo brahma vo grhe samjnānam purusebhyah

Terjemahannya:

Wahai umat manusia, persatukanlah yang menyatukan para dewa. Aku memberikan yang sama kepadamu juga sehingga anda mampu menciptakan persatuan di antara anda (Titib, 2006: 347).

Kutipan teks tersebut sangat jelas bahwa rasa solidaritas itu akan mencipatakan suatu persatuan. Mengingat manusia pada dasarnya memiliki hak yang sama yang diberikan oleh Tuhan. Ini merupakan suatu wujud keadilan bagi seluruh manusia sebagai ciptaan Tuhan. Sehingga rasa solidaritas senantiasa dijaga. Uraian yang lebih jelas mengenai sikap solidaritas terlihat dari teks $R g$ Veda X. 191.2 sebagai berikut:

Sam gacchadhvam sam vadadhvam sami vo manaìisi jānataìm

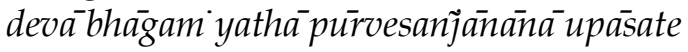

Terjemahannya:

Wahai umat manusia anda seharusnya berjalan bersama-sama, berbicara bersamasama dengan pikirana yang sama seperti halnya para pendahulumu bersamasama membagai tugas mereka, begitulah anda mestinya memakai hakmu (Titib, 1998:348)

Uraian teks tersebut sangat jelas bahwa manusia sebagai makluk sosial yang tidak dapat hidup sendiri namun senantiasa tergantung pada pihak lain melalui hubungan sosial. Melalui hubungan sosial manusia sebagai anggota dari kelompok sosial begitu juga setiap individu sebagai bagian dari aspek sosial senantaisa selalu baik 
dalam berpikir, berbicara, maupun dalam bertindak atau menjalankan tugas selalu bersama-sama. Dengan senantiasa bersama-sama maka akan mewujudkan hasil yang sama serta dapat diterima bersama-sama. Teks yang sama juga terdapat juga pada $R g$ Veda X.191.4

Saman̄i ya akutih samanā̄āhrdayā̄i vah, samañamastu vo mano yathā vah susahas̄ati

Terjemahannya:

Wahai umat manusia semoga engkau maju dengan niat-niat yang sama. Semoga hatimu (bathinmu) dan pikiranmu sama satu dengan yang lain. Sehingga anda bisa diorganisir (diatur) secara seragam (Titib, 2006: 349)

Uraian teks tersebut memperlihatkan bahwa manusia hendaknya memiliki suatu pandangan yang sama dalam menentukan suatu tujuan hidup. Antara pikiran, perkataan, serta tindakan hendaknya memiliki suatu kesamaan. Hal ini sejalan dengan ajaran Tri Kaya Parisudha tentang tiga hal yang harus disucikan agar bisa berjalan serasi meliputi; manacika yaitu pikiran yang baik, wacika yaitu perkataan yang baik, serta kaika yaitu perbuatan yang baik. Dengan berlandaskan pada ajaran Tri Kaya Parisudha makan akan berimplikasi pada hubungan solidaritas sosial yang harmonis. Lebih lanjut juga terdapat pada Atharvaveda VII.52.1 yakni;

Samjnãnam naḥ svebhịh samjnãnam aranẽbhị̣. samjnãnam aśvinā yuvam ihas̄mas̄u ni 'acchatam

Terjemahannya:

Semoga kami memiliki kerukunan yang sama dengan orang-orang yang sudah di kenal dengan akrab dan dengan orang-orang yang asing. Ya, para dewa Asvin, semoga Engkau kedua-duanya memberkahi kami dengan keserasian (keharmonisan) (Titib, 2006: 348).

Uraian teks tersebut memperlihatkan bahwa manusia senantiasa menjaga kerukunan sebagai wujud dari sikap solidaritas. Sebagai makluk sosial manusia tidak hanya berprilaku yang baik dengan orang-orang yang dikenal melainkan juga kepada orang-orang yang belum dikenal. Namun fenomen Covid-19 justru memperlihatkan adanya penutupan diri terhadap intraksi sosial. Ketakutan akan penyebarana Covid-19 membuat seseorang saling curiga terhadap orang lain. Jika dilihat dari aspek sosial maka terlihat adanya hal yang tidak sesuai dengan etika sosial, yang dimana etika sosial memberikan pemahaman tentang manusia yang tergantung pada aspek sosial. Bahkan dalam teks-teks weda sebagai sumber teologis juga senantiasa mengajarkan untuk senantiasa menjalan hubungan yang baik dengan sesama sehingga terjalain hubungan sosial yang dinamis dan harmonis 


\subsubsection{Krisis Moral}

Pada kehidupan sehari-hari istilah moral senantiasa mengiringi setiap tingkah laku manusia, moral sering diartikan sebagai tingkah laku. Dengan meminjam pendapat Bertens (2007: 4-5) moral mengacu kepada tradisi-tradisi keyakinan yang berkembang selama bertahun-tahun atau bahkan berabad-abad dalam masyarakat mengenai perilaku benar atau salah. Moralitas mengacu pada sistem nilai bagaimana manusia harus hidup baik sebagai manusia dan sistem ini terlembagakan dalam bentuk adat istiadat yang membentuk pola perilaku yang berulang dalam jangka waktu yang lama dan berisikan norma-norma yang konkret, berkaitan dengan perintah dan larangan, bersifat normatif dan mengikat yang digunakan oleh individu atau suatu kelompok sebagai pedoman dalam berperilaku.

Berdasarakan pengertian tersebut, maka moral merupakan suatu tindakan manusia yang menjadi suatu kebiasaan serta akan diwariskan secara turun temurun dan menjadi suatu adat istiadat yang baik dan buruk. Maka masyarakat Hindu juga memiliki prinsif moral yang diwariskan dan menjadi prinsif kehidupan moral seperti yang diajarkan dalam nilai kesusilaan yang menuntun manusia seharusnya senantiasa berbuat baik. Ajaran moral dalam Hindu pada dasarnya menuntun manusia untuk berbuat baik yang pada akhirnya mengarah pada kebahagiaan, kebahagiaan yang dimaksud bukan hanya kebahagiaan secara lahiriah yang dipengaruhi oleh nilai suatu obyek material, namun lebih mengarah pada kebagian rohani yang tidak terlepas dari keberadaan Tuhan. (Putra, 2020:114-125). Inti ajaran moral pada masyarakat Hindu adalah Tri Kaya Parisudha yakni ajaran moral yang menekankan tiga aspek yaitu berpikir yang baik, berkata yang baik, dan berbuat yang baik. Ketiganya harus bisa berjalan secara konsisten.

Tri Kaya Parisudha merupakan ajaran subtansi dari teologi moral. Mengingat kehidupan manusia tidk terlepas dari ajaran ini. Ajaran Tri Kaya Parisudha sebagai ajaran teologi moral berlaku dalam kehidupan manusia dalam dimensi individu dan dimensi sosial. Dalam dimensi individu ajaran Tri Kaya Parisudha menuntun agara manusia senantiasa melakukan disiplin moral dengan selalu berpikir, berkata, serta berbuat yang baik untuk permurnian jiwa yang baik. Dalam dimensi sosial maka manusia bisa berpikir, berkata, dan berbuat yang baik kepada orang lain maupun sesama. Mengingat manusia sebagai makluk sosial tidak terlepas dari intraksi sosial. Dalam intraksi ini manusia diharapkan bisa menjaga ajaran moral dalam agama Hindu. 
Dengan menjaga ajaran moral, maka manusia bisa mengatur diri dari pengaruh masalah moral yang kian marak terjadi.

Salah satu yang saat ini menjadi penyebab penyimpangan moral adalah fenomena Covid-19 yang melanda berbagai negara. Fenomena ini menjadi penyumbang adanya krisis moral yang terjadi dalam kehidupan masyarakat. Covid-19 yang terjadi secara tidak langsung menjadikan sesorang diserang secara fisik dan fsikis yang ditandai dengan rasa takut jika terjangkit oleh virus Covid-19. Mengingat penyebarannya bisa terjadi dari aktifitas intraksi langsung. Rasa takut ini membuat rasa curiga yang berlebihan kepada orang lain, menuduh seseorang secara berlebihan serta mengakimi orang lain dan berdampak pada pembatasan diri untuk bergaul ataupun menjalin hubungan yang baik dengan orange lain. Padahal dalam ajaran moral manusia dituntut untuk berbuat baik kepada orang lain.

Krisis moral yang terjadi bisa terlihat dari banyaknya masalah moral dalam kehidupan masyarakat seperti maraknya kasusprncurian diberbagai tempat. Kurangnya pemahaman moral mendorong seseorang untuk menngambil jalan pintas dalam setiap keputusan seperti pencurian. Maraknya kasus pencurian pada situasi pandemi Covid-19 seperti yang dilansir https://www.kompasiana.com/ 18/07/20/. Pencurian yang terjadi pada masa pandemi bertolak belakang dengan nilai kesusilaan dalam ajaran susila mencuri adalah berbuatan yang dilarang yang biasa dikenal dengan istilah Asteya tidak mencuri. Selain pencurian, pembunuhan juga marak terjadi saat pandemi Covid-19 yang mana pembunuhan dilakukan dari krisis ekonomi, sosial dan moral. Padahal, dalam ajaran susila pembunuhan itu dilarang seperti dalam ajaran Ahimsa yang artinya tidak menyakiti atau membunuh. Hal yang cukup marak terjadi dimasa pandemi Covid-19 yaitu maraknya perceraian dalam masyarakat seperti yang dilansir darihttps://www.nusabali.com/(05/07/20_Dalam agama Hindu seseorang yang sudah menikah atau Grahasta Asrhama diwajibkan membina hubungan keluarga yang baik. Sehingga, perceraian dalam ajaran agama Hindu tidak dianjurkan.

Bebagai krisis moral dalam bentuk masalah moral yang terjadi bertentangan dalam ajaran kesusilaaan. Nilai kesusilaan ini berrsumber dari ajaran agama Hindu yang bisa terlihat dari Sarasamuccaya 76 sebagai berikut:

Nihan yang tan ulahakena, syamati mati, mangahal ahal, siparadara, nahan tang telu tan ulahakena ring asing ring parihasa, ring apatkala, ring pangipyan tuwi singgahana juga

Terjemahannya:

Inilah yang tidak patut dilakukan, Membunuh, Mencuri, Berbuat zina 
Ketiganya janganlah hendaknya dilakukan terhadap siapapun baik secaraberolok-olok, dalam keadaan dirundung malang, dalam hayalan sekalipun, hendaknya dihindari semua itu (Kajeng, 1997: 67)

Pada uraian teks tersebut sangat jelas diajarkan bahwa membunuh, mencuri, berzina tidak boleh dilakukan karena bertentangan dengan ajaran moral yang bersumber dalam ajaran agam Hindu.

Mengingat pikiran merupakan sumber dari segala yang dilakukan oleh manusia seperti yang tertuang dalam Sarasannuscaya 82 sebagai berikut

Lawan tattwa niking manah, nyang mata wuwusanta, nag mulat ring sarwa wastu, manah juga sahaya ning mata nikan wulat, kunang yan wayakula manahny, tan ilu sumahayang mata, mulata towi nikang wastu, tan katon juga ya de nika, apan manah ikang wawarengo ngaranya hinganyan pradhanang manah kalinganika.

Terjemahannya:

Dan lagi sifat pikiran itu, bahwa mata dikatakan dapat melihat berbagai barang, tiada lain hanya pikiran yang menyertai mata itu memandang. Maka jika pikiran bingung atau kacau, tidak turut menyertai mata sungguhpun memandang pada suatu barang, tidak terlihat barang itu olehnya, sebab pikiran itulah sebenarnya yang mengetahui. Sebab itu sesungguhnya pikiranlah yang memegang peranan utama. (Kajeng, 1997: 81-82)

Dalam kitab-kitab agama Hindu banyak sekali terdapat ajaran-ajaran yang membimbing pikiran menjadi baik dan suci. Demikian pula halnya dalam kitab Sarasamuccaya kita dapati banyak ajaran yang demikian.

\section{PENUTUP}

Fenomena Covid-19 merupakan suatu masalah global yang dihadapi oleh sebagaian besar negara. Hal ini terlihat dari kian bertambahnya korban dari penyebaran Covid-19. Korban yang terdampak dari penyebaran Covid-19 ini selain terganggu masalah kesehatan juga terganggu pada masalah yang lain seperti maslah ekonomi, masalah sosial, serta masalah moral. Dari aspek ekonomi banyaknya pemutusan hubungan kerja yang terjadi dan pada akhirnya adanya penganggguran, banyaknya pengangguran terkadang berpengarah pada masalah sosial dan moral. Selain masalah ekonomi, masalah sosial juga tidak bisa dilepaskan dari masa pandemi Covid-19.

Pembataan sosial membuat kurang adanya intraksi antar individu dan pada akhirnya kurangnya hubungan yang harmonis dalam kehidupan masyarakat. Masalah yang paling menjadi sorotan yaitu adanya masalah moral yang disebabkan dari penyebaran Covid-19. Banyak terjadi masalah moral yang terjadi, seperti pencurian. Masalah-masalah yang ditimbulkan kiranya perlu mereplesikan diri dengan 
pendekatan konsep moral yang berkaitan dengan teologis atau biasa disebut dengan teologi moral.

\section{DAFTAR PUSTAKA}

Bertens, K. 2007. Etika. Jakarta: PT Gramedia Pustaka Utama.

Kaelan. 2015. Model Penelitian Kualitatif Inderdisipliner. Yogyakarta: Paradigma.

Kajeng, I Nyoman. 1997. Sarasamuscaya. Surabaya: Paramita

Pudja, G. 2013. Bagavad Gitā(Pañ̃ama Veda). Surabaya: Paramita

Putra, I Wayan Sunampan. 2020. Hedonisme Epikuros dalam Persfektif Etika Hindu. Sanjiwani Jurnal Filsafat. No 11. Volume 2.

Santosa, Slamaet. 2010. Teori-Teori Psikologi Sosial. Bandung: PT Refika Aditama.

Titib, I Made. 2006. WEDA: Sabda Suci Pedoman Praktis Kehidupan. Surabaya: Paramita. https:// bangka.tribunnews.com/2020/03

www.detik.com, 11/04/2020

https://www.nusabali.com/(05/07/20

https://www.kompasiana.com/ 18/07/20/ 